\title{
PENEGAKAN HUKUM PELAKU PELONCO BULLYING TERHADAP MAHASISWA BARU (PERSPEKTIF SOSIOLOGI HUKUM)
}

\author{
Aldi Putra \\ Magister Ilmu Hukum \\ Universitas Sebelas Maret \\ E-mail: aldiputra2087139@gmail.com
}

\begin{abstract}
This research focuses on law enforcement against acts of hazing that are based on bullying in the college environment in the New Student Life Introduction (PKKMB) activity with the victim being a student from the Faculty of Engineering, Bengkulu University with bullying. Bullying is an act of violence committed by someone who has power by oppressing the victim both physically and verbally. The victim was subjected to verbal abuse by being forced to cross her own face with lipstick by forcing a high tone and was ordered to stand for 2 hours during the Introduction to Humanity at the Faculty of Engineering Campus. In this study, using the doctrinal method (normative) by analyzing cases studied with related regulations and legal theory according to the research. Actions carried out by perpetrators of perpleoncoan with the accusation of bullying include criminal acts by means of coercion in accordance with the Criminal Code. Based on the perspective of legal sociology that law is seen based on reality on the ground (empiric), in this study usingtheory lawas a tool of social engineering. who viewed "the law as a tool to tool of engineering". In this case, it is seen that in theory the law used is that the law is made based on the reality on the ground to be a correction to the existing legal umbrella. However, this case is a fairly common problem in hazing, but bullying done by seniors to new students of Bengkulu University from the Faculty of Engineering is a hazing which should not be done on the basis of humanist principles. Laws should be dynamic in nature and change according to people's lives, but such actions must be changed if they harm others on the basis even though they are based on habits
\end{abstract}

Keywords: Law Enforcement, Freshman of Bullying, Sociology of Law.

\begin{abstract}
Abstrak
Penelitian ini berfokus pada penegakan hukum terhadap tindakan perpeloncoan yang yang dilandasi pada tindakan bullying di lingkungan perguruan tinggi dalam kegiatan Pengenalan Kehidupan Mahasiswa Baru (PKKMB) dengan korban seorang mahasiswi dari Fakultas Teknin Universitas Bengkulu dengan tindakan bullying. Bullying adalah suatau tindakan kekerasan yang dilakukan oleh sesorang yang memiliki kekuasaan dengan cara menindas korban baik secara fisik maupun verbal. Korban mendapatkan perlakuan kekerasan secara verbal dengan dipaksa mencoret wajahnya sendiri dengan lipstick dengan memaksa nada tinggi serta diperintah untuk berdiri selama 2 jam pada kegiatan Pengenalan Kehipuan Kampus Fakultas Teknik. Pada penelitian ini menggunakan metode doktrinal (normatif) dengan menganalisis kasus dikaji dengan peraturan terkait dan teori hukum yang sesuai penelitian. Tindakan yang dilakukan oleh pelaku perpleoncoan dengan diseratai bullying termasuk karenah pidana dengan adanya pemaksaan sesuai Kitab Undang-Undang Hukum Pidana. Berdasarkan perspektif sosiologi hukum bahwa hukum dilihat berdasarkan kenyataan di lapangan (empirik), dalam penelitian ini
\end{abstract}


menggunakan teori law as a tool of social engineering yang dipandang bahwa hukum sebagai alat untuk mengontrol masyarakat. Dalam kasus ini dipandang secara teori yang digunakan hukum adalah hukum sebekumnya dibuat berdasarkan kenyataan di lapangan untuk menjadi koreksi terhadap payung hukum yang ada. Namun kasus ini menjadi permasalahan yang cukup lumrah dalam perpeloncoan, namun bullying yang dilakukan oleh senior tehdap mahasiswa baru Universitas Bengkulu dari Fakultas Teknik merupakan suatu perpeloncoan yang seharusnya tidak dilakukan dengan dasar asas humanis. Hukum seharusnya bersifat dinamis berubah sesuai kehidupan masyarakat, namun tindakan seperti itu harus diubah apabila merugikan orang lain atas dasar walau berdasarkan kebiasaan.

Kata Kunci: Penegakan Hukum, Pelonco Bullying, Sosiologi Hukum.

\section{A. Pendahuluan}

Dalam dunia pendidikan, terutama di lingkup pergurauan tinggi baik negeri maupun swasta setelah melakukan berbagai seleksi seperti Seleksi Nasional Masuk Perguruan Tinggi Negeri (SNMPTN), Seleksi Bersama Masuk Perguruan Tinggi Negeri (SBMPTN), dan melalui jalur Mandiri yang setiap Universitas memiliki julukan atau slogan masingmasing namun kerap dikenal dengan Seleksi Masuk Mandiri (SMM). Pada lingkup swasta juga beberapa memiliki seleksi yang serupa dan memiliki waktu pendaftran juga cenderung lebih panjang. Dan terdapat pula seleksi dari sekolah yang bersifat kedinasan yang dibawahi oleh Kementerian yang bersangkutan dan lembaga negara lainnya Undang-Undang Nomor 12 Tahun 2012 tentang Pendidikan Tinggi, kemudain adanya peraturan dibahwanya yaitu Peraturan Pemerintah Nomor 4 Tahun 2014 tentang Penyelenggaraan Pendidikan Tinggi dan Pengelolaan Perguruan Tinggi; Peraturan Menteri Riset, Teknologi, dan Pendidikan Tinggi tentang Penerimaan Mahasiswa Baru Program Sarjana pada Perguruan Tinggi Negeri.

Setelah memingikutu seleksi dan dinyatak diterima oleh pihak universitas maka mahasiswa akan diwajibkan untuk melakukan pendaftaran ulang dan melakukan pembayaran Uang Kuliah Tunggal (UKT) yang nilainya beraneka ragam sesuai dengan kemampuan dari orang tua ataupun wali dari calon mahasiswa baru bahkan terdapat adanya beasiswa bagi mereka yang dianggap kurang mampu secara materi yang dikenal BIDIKMISI (Biaya Pendidikan Mahasiswa Miskin Berprestasi) sehigga setiap orang sesuai dengan UndangUndang Dasar Negara Republik Indonesia Tahun 1945 Pasal 31 ayat (1) yang berbunyi bahwa setiap warga berhak mendapat pendidikan.

Setelah melakukan semua berkas persyaratan kemudian barulah mahasiswa dikenalkan dengan kegiatan dengan sebutan Pengenalan Kehidupan Kampus Mahasiswa Baru (PKKMB) baik yang diselenggarakan oleh pihak Universitas, Fakultas, bahkan Program Studi yang melakukan kegiatan demi saling mengenal antar mahasiswa dan pola kehidupan di kampus. Namun ditahun ini, dikarenakan adanya Pandemi Covid-19 yang membuat kegiatan tersebut dilakukan secara virtual zoom.

Kegiatan PPKMB dalam penelitian ini berkaitan tentang adanya tindakan Pelonco yang dilakukan oleh senior dari kegiatan yang dilakukan oleh angkatan 2019 mahasiswa Fakultas Teknik Universitas Bengkulu yang menimpa mahasiswa baru angkatan 2020 yang mendapat makian dan perbuatan yang tidak menyenangkan yang dilakukan oleh senior secara virtual zoom sehingga memudahkan pelacakan secara digital. 
Berdasarkan kasus Pelonco yang dilakukan oleh senior sehingga membutuhkan penegakan hukum yang setimpal dan memberikan efek jera kepada pelaku agar kejadian tersebut berkurang di lingkungan kampus. Berdasarkan permasalahan tersebut penelitian ini terkait mengangkat masalah bagaimana penegakan hukum yang telah ada terhadap kasus Pelonco yang dilakukan oleh senior terhadap junior atau mahasiswa baru yang dilaksanakan oleh Fakultas Teknik Universitas Bengkulu serta bagaimana perspektif sosiologi hukum terhadap kasus yang akan diamati. Sehingga memberikan pandangan mengenai apa dampapak yang terjadi terhadap korban dan pelaku Pelonco.

\section{B. Pembahasan}

\section{Pelonco Bullying dalam Kegiatan Pengenalan Kehiduan Kampus Mahasiswa baru}

Berdasarkan pengertiannya, Pelonco adalah mahasiswa yang masih menjadi calon mahasiswa yang sedang mengikuti acara kegiatan pengenalan kampus. ${ }^{1}$ Kegiatan Pelonco biasanya dimaknai dengan pengenalan mengenai adanya tegur sapa, pengenalan dalam kegiatan yang ada seperti kegitan di luar kampus atau sering disebut organisasi mahasiswa (ORMAWA). Kasus pada penelitian ini terjadi di Universitas Bengkulu dalam lingkup kegiatan Pengenalan Kehidupan Kampus Fakultas Teknik yang melakukan perbuatan yang tidak menyenangkan.

Pelonco jika dipandang secara negatif yaitu perbuatan yang didasari dengan tindakan yang sewenang-wenang sehingga merugikan junior atau mahasiswa baru secara mental dan pesikis.

Bullying ataupun perundungan merupakan suatu perbuatan yang biasanya dengan adanya unsur-unsur seperti adanya tindakan kekerasan atau premanism dengan memberikan alasan untuk mewujudkan suatu sifat yang disiplin, taat akan aturan, merangkai karakter, serta menciptakan adanya relasi yang kuat antara senior dan junior di lingkungan pendidikan. Tidak demikian, tujuan yang diinginkan malah terciptanya suatu penyimpangan, karena diketahui tidak adanya komunikasi yang baik anatara senior dan junior serta tidak adanya harmonisasi antara keduanya. Hal-hal yang dilakukan seperti perlakuan kasar, adanya intirik hingga buruknya hubungan anatara kedua pihak, timbulnya rasa kebencian dan dendam sehingga menjadi sesuatu yang dianggap kebiasaan yang dilakukan kepada generasi-generasi berikutnya. ${ }^{2}$

Pada kasus Pelonco bullying yang dilakukan senior di Fakultas Teknik Universitas Bengkulu terhadap masiswa baru dalam kegiatan Pengenalan Kehidupan Kampus Mahasiswa Baru (PKKMB) yang pada waktu itu dilaksanakan selama dua hari yaitu pada tanggal 12 sampai 13 September 2020 yang memperlihatkan senior yang melakukan perbuatan seperti mengucapkan kata-kata kasar, memaksa mencoretcoret wajah mahasiswa baru menggunakan lipstick dengan alasan mahasiswi tersebut menggunakan sedikit riasan diwajah namun tidak berlebihan, serta memberi hukuman selama dua (2) jam untuk berdiri selama kegiatan Pengenalan Kehidupan Kampus Mahasiswa Baru (PKKMB) Fakultas Teknik Universitas Bengkulu 2020.

1 Kamus Besar Bahasa Indonesia.

2 Muhammad Hatta, "Tindakan Perundungan (Bullying) Dalam Dunia Pendidikan Ditinjau Berdasarkan Hukum Pidana Islam," Jurnal Ilmu-Ilmu Keislaman 41, no. 2 (2018): 280-301, https://doi.org/10.30821/miqot.v41i2.488. 
Pelonco dengan tindakan bullying memberikan dampak yang buruk bagi pelaku maupun korban serta institusi dalam menjaga nama baik. Sebab bullying dikategorikan sebagai suatu tindakan baik fisik maupun verbal.

Bullying adalah tindakan mengintimidasi seseorang atau lebih dengan anggapan bahwa sasarannya lemah. Bullying juga dapat dijelaskan sebagai tindakan menggunakan kekuatan atau kekuatan sendiri untuk menyakiti seseorang dan membuat seseorang mengalami trauma. Bentuk bullying dibedakan menjadi bentuk fisik dan bentuk verbal. ${ }^{3}$

Bullying adalah perbuatan yang dilakukan dengan cara mengintimidasi satu orang atau lebih, perbuatan yang dilakukan oleh pelaku bullying bahwa pelaku tersebut menganggap pihak yang akan menerima bullying adalah orang yang tidak mempunyai power (kekuasanan ataupun kewenangan). Pelaku bullying lebih merencanakan sesuatu yang di luar batas dari sesuatu yang telah ditentukan dengan melakukan cara-cara seperti mencelakakan korban, baik dengan pola menghina dengan tekanan jsmani dan psikis serta memandang secara fisik. ${ }^{4}$

Kasus yang meninpa mahasiswa baru angkatan 2020 Fakultas Teknik Universitas Bengkulu yang tidak disebutkan namnya hal ini menjadi cambuk terhadap adanya hukum yang mengatur tentang perilaku yang tidak menjadikan contoh yang baik bagi setiap kalangan.

Dalam hal tindakan pemberian sanksi memberikan keikutseraan mahasiswa yang seakan membuat suatu tindak tersebut sebgai sesuatu yang dianggap wajar karena dilakukan dengan landasan kebiasan yang dilakukan dil kalangan kehidupan pengenalan kehidupan kampus mahasiswa baru yang menyebabkan mahasiswa baru menjadi korban Pelonco yang bersifat bullying verbal dan memaksa secara keras dalam melakukan sesuatu.

Tindakan bullying juga bisa dilakukan dengan cara-cara yaitu baik secara langsung maupun melalui media online. Bullying merupakan bentuk tindakan pertama dari perilaku yang cenderung agresif, maksudnya manakala perbuatan yang dilakukan merupapakan tindakan kasar, baik fisik, kejiwaan dengan berupa media seperi perkataan atau satu kesatuan dari ketiga prilaku tersebut. Pelaku bullying melakukan aksinya dengan melihat korban yang memang pada posisi yang tidak bisa atau melakukan instruksi terhadap kegiatan ataupun pola kegiatan yang telah dibuat oleh pelaku bullying. ${ }^{5}$

Dalam kasus ini, tindakan Pelonco dengan cara bullying dilakukan melalui media internet yaitu zoom webminar Pengumuman yang dikeluarkan oleh Rektor dengan diwakili oleh Wakil Rektor Bidang Kemahasiswaan Dr.Drs. Syahrial.M.A.M.Phil. Nomor: 9072/UN30.5/KM/2020 yang bersikan disebabkan adanya pandemi Covid-19.

Salah satu bentuk kekerasan, yang salah satu dari bagian tersebut ialah "bullying" bisa dijadikan suatu pengelompokan dalam bentuk delik pidana. Pada istilahnya,

3 Evita Monica Chrysan, Yiska Marva Rohi, and Dini Saputri Fredyandani Apituley, "Penerapan Sanksi Tindakan Anak Yang Melakukan Bullying Dalam Perspektif Sistem Peradilan Pidana Anak," Jurnal Hukum Magnum Opus 3, no. 2 (2020): $162-72$.

4 Dewa Krisna Prasada, "Pengaturan Delik Pidana Terkait Tindakan Bulying Bagi Anak Di Bawah Umur," Acta Comitas Jurnal Hukum Kenotariatan 4, no. 2 (2019): 165-76, https://doi.org/10.24843/ac.2019.v04.i02.p01.

5 Evita Monica Chrysan et al., "Penerapan Sanksi Tindakan Anak Yang Melakukan Bullying Dalam Perspektif Sistem Peradilan Pidana Anak," Jurnal Hukum Magnum Opus 3, no. 4 (2020): 162-72. 
berdasarkan kamus bahwa tindak pidana merupakan makna yang yang digunakan dari istilah bahasa Belanda denghan istilah strafbaar feit. Di dalam Kitab Undang-Undang Hukum Pidana/Wetboek van Strafrech (KUHP/WvS) dikenal istilah strafbaar feit, namun pada kenyataanya makna dari hukum pidana sering dipergunakan istilah delik. ${ }^{6}$

Sehingga perbuatan tersebut menjadi permasalahan hukum yang menjadi sesuatu hal yang harus ditanggapi secara serius dengan membuat dan memberikan kejelasan mengenai dampak terhadap korban dan memberikan efek jera terhadap pelaku yang merugikan korban. Bullying pada dasarnya merupakan penyakit yang sering dijumpai dalam kehhidupan sehari-hari, namun batas akan perlakuan bullying yang memberikan prilaku yang pada dasarnya tidak bermoral atau amoral bagi setiap individu yang melakukan hal tersebut.

Kasus yang terjadi dalam ruang lingkup sekolah bahkan perguruan tinggi baik negeri maupun swasta bahka sekolah yang dibawah naungan pemerintah tetap ditemukan adanya prilaku perpeloncoan dalam kegiatan penganalan kehidupan kampus bagi anggota baru yang baru menjajakan pendidikanya yang lebih tinggi yang seharusnya memiliki dampak posistif lebih-lebih mendapat perlakuan yang sebaliknya dari pihak senior atau kakak tingkat.

Kasus yang terhadi di Universitas Bengkulu Fakultas Teknik di tahun 2020 ini menjadikan salah satu masih banykanya prilaku perpeloncoan dalam bentuk bullying terhadap mahasiswa baru yang dipaksa melakukan sesuatu dengan cara berlebihan dan perintah atau ucapan verbal yang kasar.

\section{Penegakan Hukum terhadap Kasus Perpeloncoan Secara Bullying terhadap Kegiatan Pengenalan Kehidupan Kampus Mahasiswa Baru (PKKMB)}

Penegakan hukum di Indonesia masih masih banyak adanya kekurangan, yang hal ini ini menjadikan urgensi dalam penegakan hukum. Masalah penegakan hukum seringkali ddengan adanya ketimpangan interaksi antara aspek hukum harapan dan aspek hukum dari kenyataan. ${ }^{7}$

Perilaku perPeloncoan yang terjadi dalam kegiatan pengenalan kehidupan kampus kerap kali dilakukan dengan cara yang melewati batas dengan tindakan seperti bullying yang memberikan adanya kesewenang-wenang yang dilakukan oleh senior terhadap junior. Pada pelaksanaanya, mengakibatkan dibutuhkannya penegakan hukum terhadap tindakan perPeloncoan dalam bentuk bullying.

Pengertian dari penegakan hukum pada dasarnya dapat ditafsirkan sebagai bentuk tindakan yang dilakukan untuk menjadikan hukum, baik dalam arti formil yang sempit ataupun dalam pemikiran dalam maksud lebih yang luas secara materiel, sehingga menjadikan hal-hal tersebut sebagai tuntunan dalam bersikap dan perilaku dalam melakukan perbuatan hukum, baik oleh untuk setiap individu bahkan kelompok yang bersangkutan dan juga terhadap para penegak hukum yang memiliki kewenangan

6 Yusnanik Bakhtiar, “Kebijakan Hukum Pidana Dalam Penyelesaian Kekerasan Bullying Di Sekolah,” Kebijakan Hukum VI, no. 1 (2017): 114-27.

7 Ucuk Agiyanto, "Penegakan Hukum Di Indonesia: Eksplorasi Konsep Keadilan Berdimensi Ketuhanan," Hukum Ransendental, no. 4 (2018): 493-503. 
menurut peraturan bagi mereka karena diberi tugas untuk menjamin atas terlaksananya peraturan baik yang tertulis maupun hukum masyarakat (living law) sehinnga menjadi ketentuan pada kehidupan berbangsa dan bernegara. ${ }^{8}$

Pengertian penegakan hukum merupakan hasil dari formulasi yaitu sebagai upaya untuk menjalankan hukum sebagaimana yang telah ditentukan, mengontrol aktualisasi hukum supaya tidak terjadi penyimpangan, serta apabila pelanggaran hukum terjadi maka opaya yang selanjutnya dilakukan yaitu memperbaiki peraturan tersebut yang dilanggar agar supaya bisa menjadi hukum yang sesuai dengan tujuan hukum tersebut. ${ }^{9}$

Terdapat tiga macam yang terlibat dalam metode untuk melakukan penegakan hukum seperti halnya: ${ }^{10}$

a. Pihak pembuat undang-undang

b. Aparat penegak hukum

c. Keadaan lingkungan yang meliputi pribadi warga secara keseluruhan.

Penegakan hukum yang dilakukan seharunya pada pihak yang melakukan penyelenggaraan Pengenalan kehidupan kampus Universitas bengkulu di fakultas hukum memang harus diusut apa dengan. Wakil rektor tiga bagian kemahasiswaan yaitu Syahrial dengan mencari pihak yang bertanggungjawab dan menyelidiki secara apakah kehidupan atau kebisaan yang dianggap membuat pihak pelaku bullying berprilaku demikian terhadap mahasiswa yang pada perponrolan dengancara bullying dan mendapat ucapan yang kasar merupakan sesuatu hal yang biasa.

Upaya dari penegakan hukum, merupakan yang telah disampaikan oleh Lawrence M. Friedman, hal ini didefinisikan bahwa peraturan harus dimaknai selaku dari maksud dari hukum (content of law), upaya pelaksanaan hukum (structure of law) dan kebiasaan atau budaya hukum (culture of law). Oleh sebab itu, penegakan hukum tidak tidak hanya diadakan berdasarkan peraturan yang bersifat tertulis, namun juga bagaimana memberdayakan aparat dan fasilitas hukum. Dan pokok dari hukum tersebut yaitu pentingnya upaya untuk mewujudkan budaya hukum masyarakat yang kontributif supaya terlaksananya penegakan hukum secara maksimal. ${ }^{11}$

penegakan hukum merupapakan suatu metode yang pada dasarnya dimaknai sebagai tindakan penerapan pengambilan keputusan yang memiliki dampak sehingga membuat keputusan yang kurang bersifat keras diatur dalam ajaran dalam suatu peraturan, namun hal tersebut mempunyai bagian-bagian sebagai penilaian pribadi. Pada intinya hukum dan moral sangatlah mengikat satu sama lain. ${ }^{12}$

8 Laurensius Arliman. S, "Mewujudkan Penegakan Hukum Yang Baik Di Negara Hukum Indonesia," Dialogia Iuridica: Jurnal Hukum Bisnis Dan Investasi 11, no. 1 (2019): 1-20, https://doi.org/10.28932/di.v11i1.1831.

9 Faisal Santiago, "Penegakan Hukum Tindak Pidana Korupsi Oleh Penegak Hukum Untuk Terciptanya Ketertiban Hukum," Pagaruyuang Law Journal 1, no. 1 (2017): 23-43, www.kpk.go.id/id/berita/siaran-pers,.

10 Ibid. hlm 36.

11 Cecep Wiharma, “Penegakan Hukum Legalistik Dalam Perspektif Sosiologis," Jurnal Hukum Mimbar Justitia 3, no. 2 (2017): 216, https://doi.org/10.35194/jhmj.v3i2.258.

12 Andrew Shandy Utama, "Kepercayaan Masyarakat Terhadap Penegakan Hukum Di Indonesia," Eksiklopedia Social Review 1, no. 3 (2019): 306-13. 
Penegakan hukum yang dilakukan berdasarkan peraturan yang ada di Indonesia, pihak yang melakukan perPeloncoan dengan bentuk bullying seharusnya diberlakukan dengan seadil-adilnya. Pada dasarnya, bukan saja pihak korban yang dirugikan namun pihak dari Lembaga yang menyelenggarakan tersebut juga terkena imbas dengan banyaknya spekulasi dari kalangan luar bahwa seharusnya lembaga yang bernaung di dunia pendidikan seharusnya menjalankan hakikat pendidikan dengan benar melainkan bukan buntuk melakukan bullying terhadap orang lain. Hal tersebut termasuk asal 335 ayat (1) butir 1 KUHP selengkapnya berbunyi:

"Diancam dengan pidana penjara paling lama satu tahun atau denda paling banyak empat ribu lima ratus rupiah:

a. Barang siapa secara melawan hukum memaksa orang lain supaya melakukan, tidak melakukan atau membiarkan sesuatu, dengan memakai kekerasan, sesuatu perbuatan lain maupun perlakuan yang tak menyenangkan, atau dengan memakai ancaman kekerasan, sesuatu perbuatan lain maupun perlakuan yang tak menyenangkan, baik terhadap orang itu sendiri maupun orang lain.

b. Barang siapa memaksa orang lain supaya melakukan, tidak melakukan atau membiarkan sesuatu dengan ancaman pencemaran atau pencemaran tertulis."

Penegakan hukum adalah untuk Mewujudkan keadilan, kepastian hukum dan Manfaat sosial menjadi kenyataan. Kesimpulanya bahwa penegakan hukum pada dasarnya ini adalah proses mengungkapkan ide. penegakan hukum merupakan proses mencoba menegakkan hukum, atau operasi sebenarnya dari norma hukum sebagai pedoman dalam upaya-upaya atau hubungan hukum dengan kehidupan sosial dan bernegara. ${ }^{13}$

Maka, pada dasarnya perbuatan perPeloncoan sudah mendapatkan pengaturan terkait bullying sehingga memberikan payung hukum. Namun kenyataan yang sudah mendasari perlindungan hukum tersenut tidak menutup adanya tidak ada lagi perbuatan atau aksi perPeloncoan di lingkungan mahasiswa baru yang mendasari atas dasar kebiasaan, latihan mental, dan selalu dianggap positif padahal hal tersebut banyak dilakukan secara berlebihan sehingga dapat membuat pelaku terkena hukuman sesuai payung hukum yang berlaku.

\section{Perspektif Sosiologi Hukum Terhadap Perpeloncoan Dalam Tindakan Bullying}

Pelonco pada dasarnya sesuatu yang biasa dilakukan dalam kehidupan dalam kegiatan pengenalan kehidupan dunia pendidikan salah satunya di pergurauan tinggi yang bertujuan memperkenalkan kampus atau sekolah tinggi lainnya secara menyeluruh sesuai visi misi dari instansi.

Bullying di perguruan tinggi sering disebut sebagai "perpeloncoan". Pada masa kegiatan tersebut sudah menjadi kebiasaan di dalam kegiatan kampus untuk mengadakan kegiatan pengenalan kampus yang biasa disebut Pengenalan Kehidupan Kampus Mahasiswa Baru. Tidak sesuai dengan angan, hal yang dianggap dapat mendidik mahasiswa baru dengan cara mengenalkan mahasiswa baru pada dunia kampus dan justru dijadikan ajang bullying. ${ }^{14}$

13 Moho Hasaziduhu, "PENEGAKAN HUKUM DI INDONESIA MENURUT ASPEK KEPASTIAN HUKUM, KEADILAN DAN KEMANFAATAN,” Warta Dharmawangsa, no. 59 (2019): 1-13.

14 Fitri Puspita Ayu Wulaningtyas and Arief Sudtrajat, "Praktik Bullying Mahasiswa Jurusan Pendidikan Sejarah Pada Masa 
Dalam pandangan sosiologi dikenal dengan kebiasaan. Pada kasus ini, perPeloncoan diizinkan dari pihak universitas yang menyelegarakan dengan deizin dari pihak baik Rektor yang diwakili oleh Wakil Rektor dibidang kemahasiswaan dan di lingkup fakultas yaitu Dekan yang diwakili oleh bagian kemahasisiswaan.

PerPeloncoan dengan berujung dengan bullying yang terjadi terhadap mahasiswi baru Fakultas Teknik Universitas Bengkulu menjadi salah satu permasalah bahwa adanya masalah di masyrakat. Berdasarkan asas pelaksanaan yang dimiliki oleh Direktorat Pendidikan Tinggi dengan beberapa asas seperti: ${ }^{15}$

a. Asas keterbukaan, yaitu semua kegiatan penerimaan mahasiswa baru dilakukan secara terbuka, baik dalam hal pembiayaan, materi/substansi kegiatan, berbagai informasi waktu maupun tempat penyelenggaraan kegiatan;

b. Asas demokratis, yaitu semua kegiatan dilakukan dengan berdasarkan kesetaraan semua pihak, dengan menghormati hak dan kewajiban masing-masing pihak yang terlibat dalam kegiatan penerimaan mahasiswa baru tersebut; dan

c. Asas humanis, yaitu kegiatan penerimaan mahasiswa baru dilakukan berdasarkan kemanusiaan yang adil dan beradab, dan prinsip persaudaraan serta anti kekerasan

Bullying atau Penindasan adalah perilaku, seperti akting, menggoda, atau menyela. Penggunaan media sosial yang tidak tepat dapat menyebabkan kekerasan verbal / tertulis di media sosial. ${ }^{16}$

Berdasarkan ketiga asas di atas sesuai dengan kasus yang diamati, asas humanis menjadi dasar yang memperkuat bahwa harus adanya sikap berprikemanusiaan, adil, dan juga beradab dalam kegiatan PKKMB serta dilarang untuk adanya kekerasan.

Dewasa ini, bullying dimaknai terhadap tindakan yabg lumrah dalam setiap kehidupan sektor lingkungan masyarakat Indonesia. Bullying dimaknai suatu perbuatan yang dilakukan dengan penggunaan kekeuasaan oleh sekelompok tertentu atau pun individu yang kerap kali melakukan perbuatan yang merugikan pihak yang lebih lemah seperti menyakiti baik melalui ucapan atau verbal, fisik, serta psikologis yang membuat korban menjadi tidak nyaman, merasa adanya tekanan secara psikis, hingga dapat membuat korbanya menjadi trauma akan perbuatan pelaku. ${ }^{17}$

Dalam penelitian ini secara soiologi hukum teori menurut Rescoe Pound seseorang ahli hukum terkemuka asal Ameriaka dikenal melalui teori law is a tool of social engineering" yang dapat dipahami pada dasarnya hukum merupakan sebagai instrumen rekayasa masyarakat. Mochtar Kusumaatmadja ahli hukum asal Indonesia memiliki pandangan bahwa hukum merupukan cangkupan dari unsur-unsur serta kaidah yang dapat mengotrol masyarakat, tanpater kecuali dengan lembaga serta dibuat

Pkkmb Mahasiswa Angkatan 2012," Paradigma 3, no. 2 (2015): 1-8.

15 Direktorat Jenderal Pendidikan Tinggi, "Panduan Pengenalan Kehidupan Kampus Bagi Mahasiswa Baru (PKKMB)," DIREKTORAT JENDERAL PENDIDIKAN TINGGI, 2020, https://dikti.kemdikbud.go.id/wp-content/uploads/2020/06/ Panduan-PKKMB-2020.pdf.

16 Armansyah, "Penanggulangan Cyber Bullying Sebagai Pembentukan Karakter Generasi Milenial," Seminar Nasional Online \& Call OFor Pappers, 2020, 53-61, https://jurnal.fhukum.unsur.ac.id/prosiding/article/view/439.

17 Ela Zain Zakiyah, Sahadi Humaedi, And Meilanny Budiarti Santoso, "Faktor Yang Mempengaruhi Remaja Dalam Melakukan Bullying," Prosiding Penelitian Dan Pengabdian Kepada Masyarakat 4, no. 2 (2017): 324-30, https://doi. org/10.24198/jppm.v4i2.14352. 
dalam wujud konkrit. Berdasarkan paham yang diamati menurut kedua ahli hukum yaitu Rescoe Pound dan Mochtar Kusumaatmadja memiliki kesamaan makna dalam memahami teori ini. ${ }^{18}$

Kasus pada perPeloncoan dalam bentuk bullying menjadikan permasalah yang sudah diatur dalam bentuk Keputusan Direktur Jenderal Pembelajaran Dan Kemahasiswaan Kementerian Riset, Teknologi, Dan Pendidikan Tinggi Republik Indonesia Nomor 116/B1/SK/2016 tentang Perubahan Keputusan Direktur Jenderal Pembelajaran Dan Kemahasiswaan Nomor 096/B1/Sk/2016 Tentang Panduan Umum Pengenalan Kehidupan Kampus Bagi Mahasiswa Baru.

Berdasarkan teori dari Rescoe Pound bahwa hukum sebagai alat untuk mengatur masyarakat memiliki keterkaitan dengan perspektif tentang kasus perPeloncoan bersifat bullying sehingga bahwa hukum telah ada dan menjadikan peraturan tertulis sebagai payung hukum namun kenyataan dilapangan tidak demikian. Perlakuan secara berlebihan dan memaksa korban yang dilakukan secara virtual zoom webminar oleh senior Fakultas Teknik Universitas Bengkulu membuat adanya ketimpangan antara hukum dan kenyataan.

Berdasarkan pemikiran dari Roscoe Pound pada dasarnya hukum dijadikan sebagai tolak ukur atau fingsi yang paling utama untuk menjunjung tinggi perlindungan terhadap masyarakat, berdasarkan perspektif Rescoe Pound terdapat beberapa macam kepentingan yang hukum wajib penuhi seperti keingianan publik (public intrest), keinginan perorangan (individual interest), serta interest of personality, berdasarkan dari berbagai macam kepentingan tadi hal tersebut bukanlah sesuatu yang bersifat absolut melainkan bersifat dinamis atau berubah sesuai dengan perkembangan di lingkungan masyarakat. ${ }^{19}$

Permasalahan yang terjadi, Bagi Pound teori law is a tool of social engineering yang iya kemukakan bahwa hukum seharusnya hukum dapat dipergunakan sebagai alat rekayasa masyarakat dengan tujuan untuk mendapatkan kesesuaian antara hukum dan masyarakat yang bersifat dinamis. Rescoe Pound juga beranggapan pada dasarnya hukum tersebut diimplementasikan berdasarkan dengan maksud dan tujuan memberikan keyakianan masyarakat sehingga mendapat kelegaan terhadap kebutuhan (necessary) serta pula kepentingan (interest). Pound lebih memandang kepentingan (bukanlah etika ataupun moralitas) menjadi sesuatu yang mutlak dalam percaturan hukum. Pemahamanya secara mendasar mengenai hukum karena terdapat banyaknya kepentingan yang harus dilindungi secara hukum, oleh sebab itu hukum sangat berperan dalam pemberdayaan setiap hak individu atau kelompok. ${ }^{20}$

Berdasarkan pemahaman Pound dikaitkan dengan aksi perPeloncoan yang diikut sertakan adanya bullying di dalamnya, menyebabkan hal tersebut tidak sesuai dengan peraturan baik peraturan bullying yang berdasarkan Kitab Undang-Undang Hukum Pidana, Surat Keputusan Direktur Jenderal Pembelajaran Dan Kemahasiswaan Kementerian Riset, Teknologi, Dan Pendidikan Tinggi Republik Indonesia Nomor

18 Marsudi Dedi Putra, “Kontribusi Aliran Sociological Jurisprudence,” Likhitaprajana 16, no. 2 (n.d.): 45-58.

19 Benedictus Renny See, "Peranan Hukum Sebagai Sarana Pembaharuan Masyarakat Menuju Masyarakat Indonesia Yang Sadar Hukum," Jurnal Hukum Ceraka Justitia 1, no. 1 (2020): 42-50.

20 M. Chairul Basrun Umanailo, Sosiologi Hukum, 2017, https://doi.org/10.31219/osf.io/5ymwh. 
116/B1/SK/2016 tentang Perubahan Keputusan Direktur Jenderal Pembelajaran Dan Kemahasiswaan Nomor 096/B1/Sk/2016 Tentang Panduan Umum Pengenalan Kehidupan Kampus Bagi Mahasiswa Baru, masih ditemukanya sesuatu perbuatan yang di dalam masyarakat (hal ini lingkungan perguruan tinggi) sikap perPeloncoan secara bullying yang berlebihan kerap terjadi.

Payung hukum yang ada sudah mengatur baik dari pemerintah sampai dengan peraturan terendah terkait instansi atau lembaga perguruan tinggi untuk tidak melakukan perbuatan yang tidak sesuai dengan asas humanis yang melanggar hak setiap individu untup mendapatkan namanya keadilan dan tidak mendapatkan kekerasan baik fisik maupun psikis.

Diupayakan apabila pelaksanaan perubahan peraturan terus menerus tersebut merupakan bertujuan supaya adanya hukum yang tercipta serta menjadi lebih baik. Hukum dari berbagai aspek, seharusnya menjadi lebih maju dengan adanya pelaksanaan perubahan peraturan yang bersifat dinamis seperti yang dialami saat ini. Sehingga mempermudah mewujudkan adanya sifat adil dalam penyelesaian suatu permasalahan yang mana hukum harus berkewajiban sebagai instrumen mewudujkan adanya keamanan dan adilnya setiap hak individu atau kalangan tertentu. ${ }^{21}$

Kasus pada dipandang dengan teori rescoe pound memang dibutuhkanya hukum yang dapat mengatur masyarakat sehingga mengurangi adanya perbuatan yang dilakukan oleh pelanggar-pelanggar hukum.

Kasus perPeloncoan ini, mendefinisikan secara gamblang dalam hal peranan hukum yang dimuat sebai suatu instrumen dalam penyelesaian kasus bullying oleh senior dan junior mahasiswa baru membuat hukum memberikan kontribusi lebih dengan adanya kasus ini. Korban Mahasiswi yang tidak disebutkan namanya secara asas humanis hak korban memang telah dilanggar oleh pelaku yaiu pelaku yang memang menjadi perkara yang serius dalam dunia pendidikan.

Pada dasarnya dengan tindakan yang dilakukan oleh pelaku memberikan dampak bukan hanya korban bullying namun pihak Universitas Bengkulu yang menyelenggarakan kegiatan Pengenalan Kehidupan Kampus Mahasiswa Baru (PKKMB) yang dilakukan tersebut.

Melalui teori Rescoe Pound, kasus ini digunakan teori law is a tool of social engineering bahwa hukum dalam masyarakat yaitu lembaga terkait diharapkan memberikan penurunan yang signifikan mengenai perbutan bullying yang bersifat memaksa. Tidak hanya itu, teori ini dalam kasus perPeloncoan secara bullying yang memaksakan korban untuk melakuakan sesuatu dengan nada keras tidak diperbolehkan berdasarkan panduan menyelenggarakan kegiatan Pengenalan Kehidupan Kampus Mahasiswa Baru (PKKMB) tahun 2020.

Banyak teori hukum percaya bahwa hukum harus stabil, tetapi tidak bisa diam atau kaku. Sekilas, pernyataan-pernyataan ini tampak saling bertentangan, tetapi nyatanya tidak saling bertentangan. Karena ini salah satu tahapan penting dari hukum, di satu sisi hukum harus mengandung unsur kepastian dan prediktabilitas, sehingga harus stabil.

21 Ida Hanifah, “Kebijakan Perlindungan Hukum Bagi Pekerja Rumah Tangga Melalui Kepastian Hukum,” Jurnal Legislasi Indonesia 4, no. 4 (2020): 193-208. 
Namun di sisi lain, hukum harus dinamis agar senantiasa mengikuti perkembangan kehidupan manusia. ${ }^{22}$

Dengan adanya sifat dinamis hukum, bahwa dengan adanya kasus ini seharusnya hukum dapat melihat secara langsung dengan pandangan bahwa hukum yang diberlakukan telah sesuai atau tidak. Pada dasarnya, peraturan yang dibuat telah sesuai mengenai ketentuan namun oknum atau pelaku dalam hal ini pelaku bully terhadap junior menjadikan pertanyaan besar apakah hukum yang dibuat telah sesuai dengan peraturan yang dibuat oleh Direktorat Jenderal Perguruan Tinngi Negeri bahwa masih adanya perbuatan perbuatan perPeloncoan yang bersifat bullying yang berlebihan sehingga dibutuhkan hukum yang lebih tegas lagi dalam penangannya.

Pound mengatakan, kontrol sosial diperlukan untuk memperkuat peradaban manusia karena mengontrol perilaku antisosial yang melanggar aturan tatanan sosial. Hukum sebagai mekanisme kontrol sosial merupakan fungsi utama negara, yaitu menggunakan kekerasan dengan cara mengerahkan kekuatan, dan kekerasan dilakukan secara sistematis dan teratur oleh agen yang ditunjuk untuk menjalankan tugas. Namun, Beliau menambahkan, aturan yang bersifat tertulis saja tidak cukup, perlu adanya dukungan dari lingkungan internal, pemahaman atau pola pikiran, moral dan lembaga kerohanian. Hukum adalah sistem pengajaran dengan unsur ideal dan empiris, yang memadukan teori hukum alam dan teori hukum positif. ${ }^{23}$

Bagi Pound, seseorang tidak dapat mengandalkan analisis logis dan hukum yang sepenuhnya abstrak (doktrinal) atau hukum yang berisi deskripsi realitas (empirik). Langkah yang futuristik wajib dilakukan adalah menggunakan hukum untuk mengatur perubahan, sehingga hadirnya konsep hukum baru yang menjadi alat rekayasa sosial. Kepentingan yang ada di masyarakat harus disesuaikan untuk meraih hasil yang proposrsional dan tidak adanya tumpang tindih. ${ }^{24}$

Adanya sektor seperti yang di sampaikan Pound di atas, bahwa korban perPeloncoan dengan bullying haruslah dilihat berdasarkan bagaimana yang seharusnya memang dibutuhkan pemberdayaan hukum dan implementasinya di masyarakat, namun kerap kali dilupakan mencari apa yang melandasi pelaku melakukan hal demikian. Apakah hal tersebut menjadi sesuatu kebiasaan yang buruk sedemikian rupa namun enggan pihak korban lain melaporkan karena adanya ancaman ataupun tekanan dari pihak yang memiliki kekuasaan yaitu senior korban.

Jika pada kasus perplonsoan bullying dengan memaksa, dan mengucapkan kata kasar, serta melakukan hal yang membuat korban dipermalukan membuat psikis korban terganggu, oleh karena itu hukum haruslah menjembatani permasalahan ini tidak hanya dimuat dalam suatu aturan namun dilakukan investigasi terhadap perloncoan oleh senior terhadap junior mahasiswa baru Fakultas Teknik Universitas Bengkulu yang dianggap hal itu tidak diperbolehkan menurut peraturan yang telah ada.

22 Nazaruddin Lathif, “Teori Hukum Sebagai Sarana Alat Untuk Memperbaharui Atau Merekayasa Masyarakat,” Palar | Pakuan Law Review 3, no. 1 (2017): 73-94, https://doi.org/10.33751/palar.v3i1.402.

23 Martha Eri Safira, "Law Is A Tool Of Social Engineering Dalam Penanganan Tindak Pidana Korupsi Di Indonesia Ditinjau Dari Hukum Islam Dan Perundang-Undangan Di Indonesia," Kodifikasia: Jurnal Penelitian Islam 11, no. 1 (2018): 181208, https://doi.org/10.2991/icsse-17.2018.28.

24 M. Zulfa Aulia, "Hukum Pembangunan Dari Mochtar Kusuma-Atmadja: Mengarahkan Pembangunan Atau Mengabdi Pada Pembangunan?," Undang: Jurnal Hukum 1, no. 2 (2019): 363-92, https://doi.org/10.22437/ujh.1.2.363-392. 
Pada kasus ini kuranya pendidikan hukum yang sudah dibuat yang dianggap sebagai suatu pajangan bahwa pelaksanaan ini ada yang mengatur namun pelaksanaannya tidak ada. Hukum dibuat untuk menjadi penengah di dalam permasalahan hukum baik lingkungan masyarakat bahkan lembaga pemerintah.

Kasus ini menjadi cambuk terhadap peranan hukum dalam melakukan penegakan hukum dan secara sosiologi hukum bahwa tindakan perPeloncoan dalam bentuk bullying tidaklah etis dilakukan ditambah dengan lingkangan tersebut adalah lingkungan yang menciptakan generasi muda yang dihrapkan menjadi penerus cita-cita bangsa Indonesia. Teori yang di ungkapkan oleh Mochtar Kusumaatmadja dan Rescoe Pound memang memberikan pendapat secara teoritik bahwa hukum hendaknya melihat yang ada di masyarakat yang supaya hukum dan kasus yang bersifat bullying dilingkungan pendidikan dapat berkurang secara signifikan.

Berdasarkan paradigma tersebut, status hukum diposisikan sebagai kekuatan yang dapat menyebabkan perubahan perilaku sosial. Artinya, teori hukum yang menjadi dasar penegakan hukum diposisikan sebagai semangat normatif yang dapat memodernisasi kehidupan masyarakat, bangsa, dan negara. Dalam paradigma yang demikian, terdapat informasi yang edukatif (pendidikan) yang dituangkan melalui penegakan hukum. Secara teori, hukum yang berlaku dalam masyarakat merupakan kumpulan aturan atau norma yang dapat mendidik masyarakat menuju suatu tujuan yaitu keseimbangan. ${ }^{25}$

Berdasarkan sosiologi hukum, pada teori hukum sebagai alat untuk mengatur masyarakat. Pada dasarnya pemberlakuan sudah sangatlah tepat dan kerap mejadi pertimbangan teori yang hampir sempurna dalam mengupayakan penyelesaian kasus seperti perPeloncoan bagi mahasiswa baru oleh senior bahwa hukum haruslah bersifat dinamis dengan memberikan pemberlakuan sanksi terhadap pelaku karena pada kasus ini pelaku belum diketahui mendapatkan sanksi yang belum diterima oleh pelaku bullying, sehingga membutuhkan penjelasan yang konkrit dari pihak universitas terutama fakultas apakah mendapat sanksi seperti mendapatkan surat teguran dari universitas atau Fakultas Teknik Universitas Bengkulu.

Hukum yang telah dibuat memnjadikan sesuatu hal tersebut menjadi krusial yang mana hukum seharusnya bisa mengikuti prilaku masyarakat dalam hal ini sektor pendidikan untuk mengkaji lagi tindakan perPeloncoan tersebut.

Di kasus perPeloncoan berlandasarkan bullying korban sudah mendapatkan haknya untuk mendapatkan pembinaan secara langsung yang telah di lakukan oleh pihak Universitas Bengkulu. Namun pihak universitas belum melakukan kewajibanya untuk memberlakukan apa yang seharusnya diterima oleh pelaku tersebut.

Secara hukum yang ada di masyrakat (living law) memang tidak memungkiri bahwa bullying terkadang dianggap sesuatu yang sepele, namun peran dari teori yang dibuat ahli hukum Rescoe Pound dan Mochtar Kusumaatmaja merupakan salah satunya bahwa hukum harus bersufat melihat kasus di semua sektor termasuk dalam pelaksanaan pengenalan kehidupan kampus yang kerap melakukan pertentangan padahal hukum yang memberlakukan, hal ini dikarenakan perPeloncoan tersebut yang buruk dilakuakan dianggap suatu kebiasaan sehingga hukum berada ditengah dalam hal ini.

25 Aminah Tnajung, "Peranan Hukum Sebagai Alat Untuk Merubah Masyarakat Dalam Kehidupan Sehari-Hari," Jurnal Warta Dharmawangsa 47 (2016): 1-15. 


\section{Kesimpulan}

Penegakan hukum pada setiap tindakan yang melanggar hukum harusalah dijunjung sesuai dengan keadilan dan kewajiban serta hak. Pada kasus ini hukum berperan dalam mengatasi permasalahan mengenai perPeloncoan dalam bentuk bullying yang menimpa mahasiswi baru Fakultas Teknik Universitas Bengkulu. Hal ini dengan adanya tindakan senioritas oleh senior panitia Pengenalan Kehidupan Kampus Mahasiswa Baru (PKKMB) Fakultas yang memperlakukan salah satu mahasiswi yaitu korban dengan memaksa mencoter muka dan berdiri selama 2 jam dalam PKK Fakultas Berlangsung. Hal tersebut masuk dalam kategori bullying. Bullying dapat dipahami tindakan intimidasi baik fisik maupun non fisik. Hal itu tentu bertentangan dari peraturan PKKMB dari Direktorat Jenderal Perguruan Tinggi Negeri serta tindakan tersebut masuk keran Hukum Pidana dalam hal perbuatan tidak menyenangkan dan memaksa. Sosiologi hukum berdasarkan perspektif ahli hukum rescoe pound bahwa hukum harus mengikuti atau mengatur masarakat yang pola kehipan bersifat dinamis. Namun pada kasus ini ditemukan ketidak sesuaian antara hukum dan kenyataan tersebut, praktek atau implementasi hukum tidak dijalankan karena hal tersebut merupakan suatu kebiasan yang buruk dan peran hukum berdasarkan teori law as a tool of enngenering memukakan bahwa hukum harus melihat keadaan lapangan bukan sekedar dibuat tanpa adanya aksi konkrit dari pelaku yang berperan di dalamnya.

\section{Daftar Pustaka}

Agiyanto, Ucuk. "Penegakan Hukum Di Indonesia : Eksplorasi Konsep Keadilan Berdimensi Ketuhanan.” Hukum Ransendental, no. 4 (2018): 493-503.

Arliman. S, Laurensius. "Mewujudkan Penegakan Hukum Yang Baik Di Negara Hukum Indonesia." Dialogia Iuridica: Jurnal Hukum Bisnis Dan Investasi 11, no. 1 (2019): 1-20. https://doi.org/10.28932/di.v11i1.1831.

Armansyah. "Penanggulangan Cyber Bullying Sebagai Pembentukan Karakter Generasi Milenial." Seminar Nasional Online \& Call OFor Pappers, 2020, 53-61. https://jurnal. fhukum.unsur.ac.id/prosiding/article/view/439.

Aulia, M. Zulfa. "Hukum Pembangunan Dari Mochtar Kusuma-Atmadja: Mengarahkan Pembangunan Atau Mengabdi Pada Pembangunan?" Undang: Jurnal Hukum 1, no. 2 (2019): 363-92. https://doi.org/10.22437/ujh.1.2.363-392.

Bakhtiar, Yusnanik. "Kebijakan Hukum Pidana Dalam Penyelesaian Kekerasan Bullying Di Sekolah." Kebijakan Hukum VI, no. 1 (2017): 114-27.

Chrysan, Evita Monica, Yiska Marva Rohi, and Dini Saputri Fredyandani Apituley. "Penerapan Sanksi Tindakan Anak Yang Melakukan Bullying Dalam Perspektif Sistem Peradilan Pidana Anak." Jurnal Hukum Magnum Opus 3, no. 2 (2020): 162-72.

Chrysan, Evita Monica, Yiska Marva Rohi, Dini Saputri, and Fredyandani Apituley. "Penerapan Sanksi Tindakan Anak Yang Melakukan Bullying Dalam Perspektif Sistem Peradilan Pidana Anak." Jurnal Hukum Magnum Opus 3, no. 4 (2020): 162-72.

DIREKTORAT JENDERAL PENDIDIKAN TINGGI. "Panduan Pengenalan Kehidupan Kampus Bagi Mahasiswa Baru (PKKMB).” DIREKTORAT JENDERAL PENDIDIKAN 
Aldi Putra. Penegakan Hukum Pelaku Pelonco Bullying terhadap Mahasiswa Baru...

TINGGI, 2020. https://dikti.kemdikbud.go.id/wp-content/uploads/2020/06/PanduanPKKMB-2020.pdf.

Hanifah, Ida. "Kebijakan Perlindungan Hukum Bagi Pekerja Rumah Tangga Melalui Kepastian Hukum.” Jurnal Legislasi Indonesia 4, no. 4 (2020): 193-208.

Hasaziduhu, Moho. "Penegakan Hukum Di Indonesia Menurut Aspek Kepastian Hukum, Keadilan Dan Kemanfaatan." Warta Dharmawangsa, no. 59 (2019): 1-13.

Hatta, Muhammad. "Tindakan Perundungan (Bullying) Dalam Dunia Pendidikan Ditinjau Berdasarkan Hukum Pidana Islam.” Jurnal Ilmu-Ilmu Keislaman 41, no. 2 (2018): 280301. https://doi.org/10.30821/miqot.v41i2.488.

Kamus Besar Bahasa Indonesia, n.d.

Lathif, Nazaruddin. "Teori Hukum Sebagai Sarana Alat Untuk Memperbaharui Atau Merekayasa Masyarakat." Palar | Pakuan Law Review 3, no. 1 (2017): 73-94. https:// doi.org/10.33751/palar.v3i1.402.

Prasada, Dewa Krisna. "Pengaturan Delik Pidana Terkait Tindakan Bulying Bagi Anak Di Bawah Umur." Acta Comitas Jurnal Hukum Kenotariatan 4, no. 2 (2019): 165-76. https:// doi.org/10.24843/ac.2019.v04.i02.p01.

Putra, Marsudi Dedi. “Kontribusi Aliran Sociological Jurisprudence." Likhitaprajana 16, no. 2 (n.d.): $45-58$.

Safira, Martha Eri. "Law Is A Tool Of Social Engineering Dalam Penanganan Tindak Pidana Korupsi Di Indonesia Ditinjau Dari Hukum Islam Dan Perundang-Undangan Di Indonesia." Kodifikasia: Jurnal Penelitian Islam 11, no. 1 (2018): 181-208. https://doi. org/10.2991/icsse-17.2018.28.

Santiago, Faisal. "Penegakan Hukum Tindak Pidana Korupsi Oleh Penegak Hukum Untuk Terciptanya Ketertiban Hukum." Pagaruyuang Law Journal 1, no. 1 (2017): 23-43. www.kpk.go.id/id/berita/siaran-pers,.

Benedictus Renny See. "Peranan Hukum Sebagai Sarana Pembaharuan Masyarakat Menuju Masyarakat Indonesia Yang Sadar Hukum." Jurnal Hukum Ceraka Justitia 1, no. 1 (2020): 42-50.

Shandy Utama,Andrew. "Kepercayaan Masyarakat Terhadap Penegakan Hukum Di Indonesia." Eksiklopedia Social Review 1, no. 3 (2019): 306-13.

Tnajung, Aminah. "Peranan Hukum Sebagai Alat Untuk Merubah Masyarakat Dalam Kehidupan Sehari-Hari." Jurnal Warta Dharmawangsa 47 (2016): 1-15.

Umanailo, M. Chairul Basrun. Sosiologi Hukum, 2017. https://doi.org/10.31219/osf.io/5ymwh.

Wiharma, Cecep. "Penegakan Hukum Legalistik Dalam Perspektif Sosiologis." Jurnal Hukum Mimbar Justitia 3, no. 2 (2017): 216. https://doi.org/10.35194/jhmj.v3i2.258.

Wulaningtyas, Fitri Puspita Ayu, and Arief Sudtrajat. "Praktik Bullying Mahasiswa Jurusan 
Pendidikan Sejarah Pada Masa Pkkmb Mahasiswa Angkatan 2012." Paradigma 3, no. 2 (2015): 1-8.

ZAKIYAH, ELA ZAIN, SAHADI HUMAEDI, and MEILANNY BUDIARTI SANTOSO.

"Faktor Yang Mempengaruhi Remaja Dalam Melakukan Bullying." Prosiding Penelitian Dan Pengabdian Kepada Masyarakat 4, no. 2 (2017): 324-30. https://doi.org/10.24198/ jppm.v4i2.14352. 